Arhe XVIII, 35/2021

UDK 159.964

801.73

DOI https://doi.org/10.19090/arhe.2021.35.335-353

Originalni naučni rad

Original Scientific Article

GORDANA VULEVIĆ ${ }^{1}$

Univerzitet u Beogradu, Filozofski fakultet

\title{
MEŠOVITA PRIRODA PSIHOANALITIČKOG DISKURSA
}

Sažetak: Frojd se, još od svoje monografije $O$ afaziji, distancirao od neurološkog redukcionizma svojih savremenika. Ukazujući da se fenomen afazije mora razumeti nezavisno od lokalizacije lezije, Frojd je doprineo svojem potonjem razumevanju fenomena histerije. Histerični simptom se ne može svesti na degenerativne promene centralnog nervnog sistema. U slučaju histerije, predstava reči biva otcepljena od predstave stvari. Neurotični simptom se, na tome će se upravo i bazirati potonja Frojdova doktrina, upravo, otklanja onda kada se tokom psihoterapijskog procesa poveže predstava reči sa predstavom stvari. Odnosno, kada se verbalizuju nesvesni sadržaji koji leže u osnovi simptoma. Diskurs pacijenta, njegove slobodne asocijacije, bitno profiliše drugi diskurs; tj. pacijentovo nesvesno. U analitičkoj situaciji, ono (nesvesno) nam se otkriva kao diskurs. Dakle, kao nešto što (uvek, nekako tek) valja protumačiti, a onda i (kao protumačeno) razumeti. Da nije tako, besmisleno bi bilo klasično određenje psihoanalize kao talking cure. To je nesporno. Ipak, da bi to talking uopšte moglo biti cure, neophodna je suštinska povezanost simboličkog i energetskog. Lingvistička re-interpretacija, nastavlja Riker, ne predstavlja alternativu ekonomskoj eksplanaciji. Dinamika značenja nužno podrazumeva telesno (energetsko)

Ključne reči: psihoanaliza, diskurs, nesvesno, energetika, hermeneutika

U vreme Frojdovog rada na (obimom nevelikoj, svakako značajnoj) monografiji posvećenoj afaziji, ${ }^{2}$ u pitanju je sam kraj 19. veka, tadašnja

\footnotetext{
${ }^{1}$ E-mail adresa autorke: gvulevic @f.bg.ac.rs

${ }^{2}$ Freud, S., Zur Auffassung der Aphasien, Franz Deuticke, Leipzig und Wien 1891. Nešto ranije (u pitanju je godina 1888) Frojd će, u jednom onovremenom
} 
neurologija i psihijatrija su bile na pozicijama fiziološkog redukcionizma. Prema teoriji koju su svojevremeno razvili Vernike i njegov učenika Lihtehajm, mentalni fenomeni striktno bivaju locirani u nervnom tkivu. ${ }^{3}$ Štaviše, tada se smatralo, da je svaka mentalna bolest, zapravo, bolest mozga. ${ }^{4}$

Otud, klasično (neurološko) shvatanje afazije. Smatralo se da enkodirani sonični stimulus putuje akustičkim putevima u čisto fiziološkom obliku, stižući tako do auditivnog korteksa, gde, potom, biva transformisan u svesne senzacije zvuka. Potom, one ekscitiraju odgovarajuće ćelije u Vernikeovom centru. Upravo te ćelije imaju moć da transformišu percipirane zvuke u sećanje reči. Tek tako procesuirane reči, konačno, mogu postati prepoznatljive (kao reči, a ne više samo kao zvuci) sledstveno njihovom prenosu u odgovarajuće centre specijalizovane za konceptualno mišljenje. Iz bilo kog od dva pomenuta centra (Vernikeov i Brokin) senzorne slike reči mogu da ekscitiraju motoričke slike reči, locirane u Brokinom centru za govor. Ćelije Brokinog centra stimulišu motorne centre precentralnog girusa, koji, pak, kontroliše same glosofaringijalne organe govora. ${ }^{5}$ Tako se, dakle, nekada mislilo.

U svojoj monografiji $O$ afaziji Frojd, s valjanim razlozima, dovodi u pitanje klasičnu teoriju lokalizacije. Koristeći se retorikom njemu savremene neurologije, on, zapravo, bitno posmatrano, već sada možemo reći, u samoj biti psihoanalize (kao teorije i kao prakse) bila je težnja da se jedan novi diskurs, diskurs psihoanalize, doista, kritički emancipuje od tada

dijagnostičkom priručniuku (A.Villaret Handwörterbuch der gesamten Medizin) napisati odrednicu, upravo, posvećenu afaziji.

${ }^{3}$ Up. Solms, M, "Before and After Freud's Project" in: Neuroscience of the Mind, ed. Bilder R, LeFever F. F. New York: The New York Academy of Science, 1998.

${ }^{4}$ Posredi je poznat, nekad često navođen, stav Vilhelma Grisingera, uglednog nemačkog lekara. Up. Griesenger, W., Mental Pathology and Therapeutics, William Wood \& Company 1882, str. 1-9. Knjiga je izvorno objavljena na nemačkom, pod naslovom: Pathologie und Therapie der psychischen Krankheiten. Stuttgart: Krabbe, 1845; second edition, Braunschweig 1861. Engleski prevod koji ja ovde navodim urađen je po drugom izdanju.

${ }^{5}$ Up. Solms, M, "Before and After Freud's Project", in: Neuroscience of the Mind, ed. Bilder R, LeFever F. F., The New York Academy of Science, 1998, p. 1-11. 
dominantnog diskursa nauke. Iskoračuje iz okvire te iste (u njegovo vreme aktualne) neurološke nauke. Pri tom, važna je sledeća napomena:

Frojd kaže: „Medicina je težila da, u skladu sa psihološkom nomenklaturom, lokalizuje mentalne sposobnosti u određene delove mozga. Izgledalo je da je napravljen veliki napredak kada je Vernike utvrdio da se samo najjednostavniji psihički elementi, različite senzorne predstave, mogu legitimno lokalizovati u zoni centralnog perifernog nerva koji je primio impresiju. Ali“, upozorava Frojd, ,zar time ne pravimo istu grešku? Da li je opravdano smatrati da fiziološka modifikacija nervnog vlakna završava $u$ sferi uma, i to kao predstava ili slika?“6 On nastavlja: „Verovatno je da lanac fizioloških događaja u nervnom sistemu ne stoji u uzročno posledičnoj vezi sa psihičkim događajima. Fiziološki događaji ne prestaju čim započnu psihički; naprotiv, fiziološki lanac se nastavlja. Ono što se dešava je jednostavno to da, u jednom trenutku, svaki (ili neki) od njegovih veza ima psihički fenomen koji mu korespondira. Prema tome, psihički proces je paralelan fiziološkom“. ${ }^{7}$

Potom, sledi njegov zaključak: „Pomenuti autori koriste se eliptičnim iskazom - predstava je locirana u nervnoj ćeliji. Za psihologiju jednostavna predstava je nešto elementarno. To je navelo na pretpostavku da je fiziološki korelat predstave takođe nešto jednostavno, nešto što se može lokalizovati na određenom mestu. Šta bi bio fiziološki korelat jednostavne predstave? Sigurno ništa statično, već nešto što je po svojoj prirodi proces... On počinje iz određene tačke u korteksu i širi se na druge delove korteksa..."8

Problemu afazije Frojd pristupa držeći po strani anatomiju i fiziologiju. U slučaju afazije, dakle, ne radi se o prekidu linearne progresije

\footnotetext{
${ }^{6}$ Freud, S., Zur Auffassung der Aphasien, Franz Deuticke, Leipzig und Wien 1891., str. 66 .

${ }^{7}$ Ibid., str. 66

${ }^{8}$ Ibid. str. 67.
} 
nervnog impulsa od senzornih do motornih vlakana, već o poremećaju veza (asocijacija) između mentalnih fenomena. ${ }^{9}$

Jezička jedinica, reč, smatra Frojd, predstavlja kompleksan mentalni fenomen. On nastaje kombinovanjem auditivnih, vizuelnih i kinestetskih elemenata. Za Frojda, akustička slika je centralni aspekt reči: primarno značenje reči je ono koje je prvobitno vezano za zvučnu sliku. Govor se, sasvim logično, usvaja na osnovu onoga što se čulo. Slično tome, za Frojda, vizuelni aspekt objekta je najvažniji kada je u pitanju objekt asocijacija. ${ }^{10}$ Već sada, na najranijem nivou razvoja svoje misli, Frojd skicira osnovnu shemu svoje potonje doktrine. Suština je, složićemo se, u (sukcesivnom i simultanom) preklapanju i saprožimanju vektora vezanih za ono viđeno $i$ ono čuveno.

Koristeći pomenuti model, Frojd je, znači, reformulisao etiologiju Vernikeove afazije. Sa neuropatološkog, težište je bitno pomereno u smeru funkcionalnog. U slučaju senzorne afazije, poremećene su veze (asocijacije) između pojedinih elemenata predstava reči, dok su u slučaju motorne afazije poremećene veze (asocijacije) između predstava reči i predstava objekata.

Ukazujući da se fenomen afazije mora razumeti nezavisno od lokalizacije lezije, Frojd je doprineo svojem potonjem razumevanju fenomena histerije. Histerični simptom se ne može svesti na degenerativne promene centralnog nervnog sistema. U slučaju histerije, predstava reči biva otcepljena od predstave stvari. Neurotični simptom se, na tome će se upravo i bazirati potonja Frojdova doktrina, upravo, otklanja onda kada se tokom psihoterapijskog procesa poveže predstava reči sa predstavom stvari. Odnosno, kada se verbalizuju nesvesni sadržaji koji leže u osnovi simptoma.

Projekat za naučnu psihologiju, pisan 1895. godine, ${ }^{11}$ bar u izvesnom smislu, razlikuje se od njegove monografije o afaziji. U Projektu,

\footnotetext{
${ }^{10}$ Up. Freud, S., Zur Auffassung der Aphasien, kao i Forester, J., Language and the Origins of Psychoanalysis, The Macmillan Press Ltd, London, 1980.

${ }^{11}$ Up. Freud, S., „Project for a Scientific Psychology“, Freud, A., Strachey, A., Tyson, A., Richards, A. (1966). The Standard Edition of the Complete Psychological
} 
kaže Riker, Frojd je pokušao da stvori kvantitativnu psihologiju želje i tako zasnuje naučnu psihologiju, uporedivu sa Fehnerovom kvantitativnom psihologijom. ${ }^{12}$ To je, zapravo, možemo zaključiti, bio Frojdov (po mnogo čemu paradoksalan) pokušaj da svoje inicijalne kliničke uvide objasni teorijskim spekulacijama. Njihovo težište težište je bilo na nekoj vrsti (ipak metaforične) anatomije; na redukcionizmu koji je u svojoj osnovi, upravo, imao takvu jednu (hipotetičku) anatomiju.

Ideja je bila, veli Frojd, stvaranje osnova za jednu (buduću) psihologiju, koja će, pri tom, biti prirodna nauka. Osnovna postavka takvog viđenja stvari bila je, u skladu sa onovremenim psihofizičkim senzibilitetom, pretpostavka mogućnosti predstavljanja psihičkih procesa kao kvantitativno determinisanih.

Konkretno, Projekat počiva na dvema tezama:

1. Ono što po čemu se razlikuje aktivnosti od mirovanja treba smatrati kvantitetom koji podleže opštim zakonima kretanja

2. Materijalne čestice koje su u pitanju su neuroni.

Brižljivo u svom tekstu, Frojd ih razvija, gradeći tako prvi praosnov svojih potonjih metapsiholoških spekulacija.

Frojdovo rano objašnjenje dinamike psihičkog aparata je zasnovano na, iz onovremene fizike pozajmljenom, principu konstantnosti. Takva, u osnovi kvazi-fizička, koncepcija psihičkog aparata, mora se priznati, nikada nije bila u potpunosti eliminisana iz Frojdove teorije. U tom smislu, karakterističan je sledeći tok Frojdovih argumenata. Princip konstantnosti on izvodi iz principa inercije. Princip inercije počiva na ideji da sistem teži da redukuje tenziju na nulu. O tome, na početku Projekta Frojd kaže: „Neuronski sistem mora da napusti svoj trend prema inerciji (to jest redukovanju tenzije na nulu). On mora da nauči da podnese određeni kvantum tenzije dovoljan kako bi odgovorio na zahteve za specifičnom

Works of Sigmund Freud, Volume I (1886-1899): Pre-Psycho-Analytic Publications and Unpublished Drafts, str. 281-391.

12 Up. Ricoeur, P., Freud and Philosophy: An essay on interpretation, Yale University Press, New Heaven, 1970. 
akcijom. Ova težnja postoji paralelno sa težnjom da se kvantitet smanji što je više moguće i da se izbegne porast tenzije..." ${ }^{\text {“13 }}$

Treba zapaziti da nam Frojd ne govori mnogo o poreklu i prirodi onaga što naziva kvantitetom. Što se tiče porekla tenzije, ona potiče iz spoljašnjih i unutrašnjih ekscitacija. Što se tiče prirode samih ekscitacija, Frojd je karakteriše kao sumu ekscitacija homolognu fizičkoj energiji. Posredi je, zapravo, kontinuirani protok energije; ona se kumulira (stvarajući tenziju), prazni (uslovljavajući rasterećenje). Kao takva, ona (ta suma ekscitacija) biva pohranjena u neuronima. Pojam katekse (zaposednuća, tj.

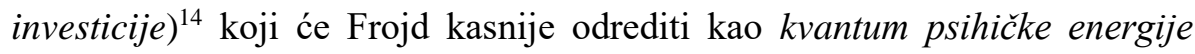
kojom se investiraju psihički fenomeni $i$ strukture, prvobitno je bio shvaćen na tragu pomenute dinamike punjenja, odnosno pražnjenja, neurona. ${ }^{15}$

$\Phi$ neuroni primaju nadražaje iz spoljašnje i unutrašnje sredine. Oni su permeabilni, tj. propustljivi. Samim tim, oni su u mogućnosti da (dalje) propuštaju različite kvantume ekscitacija, čineći to uprkos među njima postojećih kontakt barijera. Sam propust ekscitacije ne menja njihovu strukturu, ali ni funkciju. Nakon ekscitacije oni bivaju isti onakvi kakvi su bili i pre. Dakle, ekscitacija ih nije promenila. $\Psi$ neuroni su nepremaeabilni, $\mathrm{tj}$. oni su nepropustljivi. Njihove kontakt-barijere su $\mathrm{u}$ permanentno promenjenom stanju. Tako (na nivou neurološkog traga) zabeležena promena čini mogućim (psihološko) reprezentovanje sećanja. Memorija je, zaključuje Frojd, reprezentovana razlikama u facilitaciji koja postoji između $\psi$ neurona. Facilitacija će zavisiti od količine energije koja prolazi kroz neurone i broja ponavljanja tog procesa, to jest sećanje na iskustvo zavisi od snage impresije i učestalosti njenog ponavljanja. ${ }^{16}$

\footnotetext{
${ }^{13}$ Up. Freud, S., „Project for a Scientific Psychology“, The Standard Edition of the Complete Psychological Works of Sigmund Freud, Volume I (1886-1899): PrePsycho-Analytic Publications and Unpublished Drafts, str. 297.

14 Konkretnije o samom pojmu katekse u kontekstu Frojdove teorije up. O Frojdovom pojmu asocijacije, detaljnije up. Laplanche J. An Ponatalij J. B. The language of Psychoanalysis, Karnac Books 1988, str. 62-65.

${ }^{15}$ Up. Freud, S., „Project for a Scientific Psychology“ in The Standard Edition of the Complete Psychological Works of Sigmund Freud, Volume I (1886-1899): PrePsycho-Analytic Publications and Unpublished Drafts.

${ }^{16}$ Ibid.
} 
Sistem $\psi$ neurona je, sam po sebi, lišen direktnog kontakta sa spoljašnjim svetom; on prima kvantume energije od strane $\phi$ neurona, kao i iz (interioceptivnih) celularnih struktura direktno veznih za ekscitacije iz unutrašnjosti organizma. ${ }^{17}$

Priraštaj nivoa akumuliranih ekscitacija dovodi do neugode. Osećanje zadovoljstva nastaje kao posledica smanjenja kvantiteta ekscitacija. Subjektivno osećanje zadovoljstva ili nezadovoljstva Frojd lokalizuje u treći tip neurona, $\omega$ neurone. ${ }^{18}$ Ono što se u njima događa je, upravo, transformisanje kvantiteta u kvalitet. Dinamika ličnosti, ovde, samim tim, poprima obrise (intelektualno zavodljivog, u osnovi hipotetičkog) hibrida, koji sobom objedinjuje sferu subjektivnog doživljavanja sa, svemu tome pretpostavljenim, organskim supstratom. Pri tom, važno je naglasiti (a sve to u skladu sa već pomenutom tezom o bitno metaforičkom statusu Frojdovih neuroloških termina) da niko, pa ni sam Frojd (ni tada, ni posle), nije uspeo (zapravo, nije ni pokušao) da, zbilja, izdvoji neurone tipa $\varphi, \psi$ i $\omega$.

U Frojdovoj mehanicističkoj teoriji, kakva je izneta u Projektu, želja stupa na scenu posredstvom tragova sećanja vezanih za doživljaj zadovoljstva ili nezadovoljstva. Već ovde je, dakle, (implicitno) prisutna, za kasniju psihoanalizu izuzetno bitna, teza o razlici između potrebe i želje. U Projektu, dodajmo još i to, nailazimo i na prvo određenje potiskivanja, kao povlačenja katekse (tj. investicije, zaposednuća) sa neprihvatljive slike sećanja. ${ }^{19}$

Osećanje zadovoljstva ili nezadovoljstva uvodi u igru Drugog: Na ranim stadijumima razvoja ljudski organizam nije u mogućnosti da samostalno preduzme određenu akciju kako bi spustio tenziju. Smanjenje tenzije (od strane Drugog) rezultuje osećanjem zadovoljstva, i dolazi do stvaranja reprezentacije potrebe i menističke slike objekta. O tome Frojd

\footnotetext{
17 Ibid.

18 Ibid.

${ }^{19}$ Ibid.
} 
govori kao o kateksi (tj. zaposednuću, investiranosti) jednog ili više neurona, što bi korespondiralo kortikalnoj projekciji objekta. ${ }^{20}$

Na početku života, kada dominiraju primarni procesi mišljenja, oni funkcionišu u skladu sa principom zadovoljstva, tenzija može biti smanjena posredstvom rekatekse (tj. ponovne, naknadne investicije) sećanja željenog objekta; to jest, ovaj pojam će figurirati i u kasnijoj (zreloj) teoriji, posredstvom halucinatornog zadovoljenja želje. Tek progresivno narastanje frustracije (za Frojda, to bi bila ključna pretpostavka potonjeg kognitivnog razvoja) dovodi do napuštanja zadovoljenja na halucinatoran način. Umesto toga, mentalni aparat mora biti u stanju da sebi, pre svega, predstavi realne odnose spoljašnjeg sveta. ${ }^{21}$ Tek na osnovu takve (sada realistične, dakle, ne više halucinatorne) predstavljenosti sveta, subjekat se može kompetentno razabrati, a onda i snaći, u svetu (kako spoljašnjih, tako i unutrašnjih) objekata.

Kao što vidimo, princip zadovoljstva dobija svog parnjaka u jednom drugom (mnogo zrelijem) principu duševnog funkcionisanja. Frojd ga zove; princip realnosti. Pojednostavljeno rečeno, psihički aparat i dalje (sebi) predstavlja stvarnost. No, razlika je u tome, u odnosu na raniji stadijum razvoja, on to sada čini realistično; dakle, ne više halucinatorno. Inicijalni ekskluzivitet principa zadovoljstva progresivno ustupa primat principu realnosti: ono tu dominantno predstavljeno, više nije ono prijatno, već ono realno, makar bilo i neprijatno.

Govoreći iz perspektive razvoja ličnosti, opisano uspostavljanje dominacije principa realnosti, dalje, rezultuje postepenim formiranjem sekundarnih procesa mišljenja. Pre svega, pojavljuje se jedna važna funkcija: pažnja. Psihička stvarnost više nije rasuta. Subjekat je u stanju da se fokusira; da sam (aktivno) krene u susret čulnim utiscima, umesto da (pasivno) čeka njihovo nastupanje. Sa ovim povezano, javlja se i moć diskriminacije halucinacije i percepcije. Nju će Frojd, kao što znamo, pripisati egu. Sam ego tu biva viđen kao instanca koja inhibira (ili

\footnotetext{
${ }^{20}$ Ibid.

${ }^{21}$ Ibid.
} 
dezinhibira) kateksu slike sećanja, to jest ego uči da ne katektira (tj. da povlači katekse, da deinvestira) slike željenih objekata. ${ }^{22}$

Frojdov Projekat, tvrdi Riker, nije (samo) mehanički sistem generisanja eksplanacija, isključivo zasnovanih na dominaciji anatomske hipoteze. Drugim rečima, taj njegov sistem (u nastajanju), ni tada, u svojem najranijem obliku, nije u potpunosti bio lišen izvesnog hermeneutičkog naboja. U Projektu je (implicitno) prisutna topografija (primarni i sekundarni procesi mišljenja). Upravo ona otvara mogućnost interpretiranja simptoma. ${ }^{23}$

Veza koju uspostavlja Frojd između diskriminacije i inhibicije, kaže Riker, nije mehanička. Ona je deskriptivna. Mehaničke eksplanacije, upozorava Riker, pogotovo na završnim stranicama Projekta, sve više ustupaju mesto deskripcijama. ${ }^{24} \mathrm{U}$ tim deskripcijama prepoznatljivi su zametci potonje teorije i prakse tumačenja. Drugim rečima, već sada možemo reći, za samu psihoanalizu inače karakteristična hermeneutika nastaje na tragu Frojdovog doslednog emancipovanja sopstvenog mišljenja od tada preovladavajućeg (dominantno neurološkog) redukcionizma. Naravno, ovome valja dodati i sledeće pojašnjenje: distancirajući svoje mišljenje od njemu savremene nauke Frojd, ni jednom rečju koju je izrekao ili zapisao, nije želeo da porekne sam smisao nauke. Naprotiv, celim tokom svog života on je nastojao da proširi okvire postojeće nauke. Konačno, u pravu je bio Tomas Man kada je tvrdio da je Frojd, pre svega, bio čovek prosvećenosti. ${ }^{25}$

Pojam mentalne bolesti nije svodljiv u uske okvire pojma bolesti mozga. Razumevanje dinamika ličnosti, nužno, podrazumeva mnogo više od priprostog matematizovanja ekscitacije shvaćene kao veličine. Nije sve u (zbrojivoj) količini. Nešto je i u kvalitetu. No, čak ni sam kvanititet nije do kraja izraziv.

Pitanje kvantiteta (kao uostalom i pitanje kvaliteta) proističe iz Frojdove kliničke prakse. Da je tvorac psihoanalize pokazivao sklonost

\footnotetext{
${ }^{22}$ Ibid.

${ }^{23}$ Up. Ricoeur, P., Freud and Philosophy: An essay on Interpretation.

24 Ibid.

${ }^{25}$ Up. Man, T., Stvaraoci i dela, Matica srpska, Novi Sad, 1932.
} 
spekulativnom (ponekad bivajući u tome upadljivo neoprezan) nije sporno. Ipak, valja priznati, retke su njegove spekulacije (sve i da su neoprezne) koje su bile potpuno lišene veze sa njegovim, najkonkretnijim mogućim, analitičkim iskustvom.

To je, kao što vidimo, bilo očigledno već na samom početku, u njegovim ranim (meta)neurološkim spekulacijama.

U svom delu Tumačenje snova, nastojeći da teorijski formalizuje svoje ideje o strukturi i funkciji mentalnog aparata, Frojd radikalno (dakle, ne više implicitno, već sasvim eksplicitno) odustaje od svakog anatomskog (tj. neurološkog) redukcionizma. Njegova topika sna isključuje priču o (eksplanatorno validnoj) redukciji na domen kortikalnog lokaliteta. Posredi je nešto bitno drugačije; tj. pitanje psihičkog (a ne kortikalnog) lokalitea kao odredišnog toposa nastanka samog sna. ${ }^{26}$

Za Frojda, san je psihološki fenomen. On ga posmatra u kontekstu svoje, široko postavljene, teorije o dinamici psihičkog. Dinamika psihičkog nije svodljiva na dinamiku nervnog. Za razliku od neurološke eksplanacije, koja počiva na ideji svodljivosti psihičkog na organsko, Frojdovo razumevanje sna podrazumeva svest o (heurističkoj) neophodnosti ostajanja u domenu psihičkog. Da bismo ga razumeli, san moramo tumačiti. Tumačenje je stvar simbola. Simboličko izmiče organskom. Jedno je, naprosto, nesvodljivo na drugo.

Naravno, ovde valja biti obazriv. Izvorno Frojdovoj hermeneutici potpuno je stran svaki (neretko, frivolno apstraktni) formalizam. Teško je i pretpostaviti šta bi Frojd, danas, da je kojim slučajem u prilici, rekao o Lakanu. Čak je moguće da bi mu se tu ponešto i dopalo. Ipak, bojim se, izvesno je da mu se mnogo toga što je (u decenijama koje su za nama, kako u Francuskoj tako i u angloameričkom kulturnom prostoru) proizašlo iz Lakanovog učenja ne bi dopalo. Kad to kažem, prvenstveno imam u vidu (danas već uveliko prepoznatljiv) manir retoričkog građenja psihoanalitičkog diskursa lišenog svake smislene veze sa konkretnom analitičkom praksom.

${ }^{26}$ Freud, S., Tumačenje snova, Novi Sad, Matica srpska, 1969. 
Istine radi, valja i to reći, verovatno ne bi bio ništa skloniji ni današnjoj neuropsihoanalizi.

Frojd je (vrlo rano) odustao od anatomskog redukcionizma onovremene neurofiziologije. To, međutim, nikako ne znači da je odustao i od tela. O telu je, svakako, moguće govoriti kao o činjenici svima nama zajedničkog organskog supstrata. Prirodne nauke, svaka iz svog ugla, upravo to čine. Istovremeno, telo možemo posmatrati kao (pre svega energetsku) odrednicu personalnog; dakle, psihičkog. To je ono što Frojd čini.

Riker je u pravu. Tumačenje snova, kao i kasniji Frojdovi tekstovi, pokazuju da je Frojdov diskurs mešovit diskurs. U njemu se, kao takvom, nužno prepliću pitanja značenja i pitanje sile. ${ }^{27}$ Jedno bez drugog, jednostavno, gubi smisao. Frojdovu teoriju, veli Riker, možemo posmatrati kao sasvim naročitu formu razumevanja psihičkih fenomena, upravo, posredstvom konflikta sila. Otud (uz svu svesnost o važnosti simboličkog), neophodnost dosledno izvedene energetike. Istovremeno, psihoanaliza uključuje tumačenje manifestnog značenja (snova, simptoma, kulture) kroz latentno značenje, te može biti uključena u hermeneutiku. U zaleđu svega toga leži ontološki nužna dinamika energetskog naboja.

Još jednom, Riker je u pravu. Do spoznaje nesvesnih sadržaja dolazimo posredstvom tumačenja svesnih fenomena (snova, omaški, simptoma). Tumačenje (zamena jednog teksta drugim tekstom) moguće je, upravo, zahvaljujući tome što je nesvesno psihički modalitet sačinjen od reprezentacija. Frojd kaže: „Nagon nikada ne može postati objekat svesti to može samo predstava koja ga reprezentuje. On, međutim, ni u nesvesnom ne može biti reprezentovan drugačije nego predstavom. Kad se nagon ne bi držao predstave, ili ne bi bio uočljiv za afektivno stanje o njemu ne bi mogli ništa da saznamo“28. I samo Frojdovo određenje nagona sadrži psihičko određenje ove energije: „Ako razmotrimo mentalni život sa biološke tačke gledišta, nagon je koncept koji se javlja na granici između psihološkog i biološkog, kao psihički reprezentativ stimulusa koji potiču iz organizma i

\footnotetext{
${ }^{27}$ Up. Ricoeur, P., Freud and Phylosophy: An Essay on interpretation.

${ }^{28}$ Up. Freud, S., The Unconscious, SE, vol. XIV, Hogarth Press, London, 1915 ab, str.177.
} 
dopiru do uma. “29 Drugim rečima, interpretacija fenomena normalnog života (snova i omaški) kao i neurotičnog simptoma isključivo biva moguća jer je nesvesno po svojoj prirodi semiotičko. Lakan bi rekao - strukturisano kao jezik.

Važan je sledeći stav. Lingvistička re-interpretacija, nastavlja Riker, ne predstavlja alternativu ekonomskoj eksplanaciji. Dinamika značenja nužno podrazumeva telesno (energetsko) zaleđe. ${ }^{30}$ Subjekt analitičkog iskustva nije bestelesna utvara. San se ne može interpretirati ukoliko se ne uvedu u igru energetski koncepti. Isto važi i za sve ostale (neurotske ili psihotične) tvorevine duše.

Želimo li dospeti do (potisnute) želje snevača, prethodno moramo razumeti mehanizme koji uslovljavaju, za san karakteristične, simboličke distorzije izvornog (dakle, potisnutog) značenja. Drugim rečima, sledujući logiku analitičke procedure, od manifestnog moramo dopreti do onog u snu latentnog. Iskrivljavanje latentnih misli sna, veli Frojd, nastaje usled dejstva cenzure. Reći da iskrivljavanje sna nastaje usled dejstva cenzure, znači uspostaviti (ekonomsku) eksplanaciju. Cenzura je uzrok, iskrivljavanje je posledica.

Eksplanacija je, shvaćena kao uspostavljanje uzročno posledičnih odnosa, prvenstveno karakteristična za prirodne nauke. No, legitimno je zapitati se, kako stoje stvari sa eksplanacijum u kontekstu psihoanalitičkog diskursa? I tu, kao što smo videli, postoji težnja da se uspostavi nekakva veza između posledice i uzroka; tj. namera da se smisao posledice odredi posredstvom razumevanja njoj prethodećeg uzroka.

${ }^{29}$ Up. Freud, S., Instincts and Their Vicissitudes, SE, vol. XIV, Hogarth Press, London, 1915 a, str. 121-122.

${ }^{30}$ Sličnu tezu zagovarace i Andre Grin, Up. Green A., The Fabric of Affect in the Psychoanalytic Discourse, Routledge 1999. 
Psihoanalitički diskurs je, uverava nas Riker, mešovit. Podjednako je nemoguće svesti ga u okvire prirodnjačkog, ali i semiološkog redukcionizma. ${ }^{31}$

Diskurs pacijenta, njegove slobodne asocijacije, bitno profiliše $d r u g i$ diskurs; tj. pacijentovo nesvesno. $\mathrm{U}$ analitičkoj situaciji, ono (nesvesno) nam se otkriva kao diskurs. Dakle, kao nešto što (uvek, nekako tek) valja protumačiti, a onda i (kao protumačeno) razumeti. Da nije tako, besmisleno bi bilo klasično određenje psihoanalize kao talking cure. To je nesporno. Ipak, da bi to talking uopšte moglo biti cure, neophodna je suštinska povezanost simboličkog i energetskog. Shodno tome, valja zapitati se: da li su zakoni tog, kako veli psihoanaliza, drugog diskursa (diskursa nesvesnog) lingvistički zakoni u pravom smislu te reči? ${ }^{32}$

Tačnije, da li se jezik nesvesnog (ili, još bolje, nesvesno kao jezik) poklapa sa onim što de Sosir podrazumeva pod jezikom koji (za razliku od govora, žive reči) počiva na konvenciji, kako u pogledu jezičkih jedinica, tako i u pogledu pravila njihovog kombinovanja?

$\mathrm{Na}$ sve ovo, dalje, sasvim prirodno, nadovezuje se pitanje: da li je psihoanaliza (uopšte) nauka? Odnosno, kakav je njen epistemički potencijal? Te, kolika je (realna) delotvornost njene prakse?

Navedene nedoumice (a one nisu jedine, ima ih još) pokreću mnoga važna (kako teorijska, tako i praktična) pitanja. Jednostavni odgovori ne postoje. U svakom slučaju, besmisleno je govoriti o teorijskoj psihoanalizi. Ut to, ništa manje nije besmisleno govoriti ni o ateorijskoj praksi.

\footnotetext{
${ }^{31}$ Up. Ricoeur, P., Freud and Philosophy: An Essay on Interpretation.

${ }^{32} \mathrm{U}$ tom smislu možemo razumeti i Grinovu kritiku Lakana; odnosno, poznatog lakanovskog manira svođenja svega na puku dinamiku međuigre označitelja. Up. Green A., The Fabric of Affect in the Psychoanalytic Discourse, Routledge, London 1999.
} 
Psihoanaliza nije prirodna nauka. Njen objekat bitno se razlikuje od objekata kojima se bave prirodne nauke. Istovremeno, psihoanaliza nije svodljiva ni u okvire društvenih nauka. Složićemo se Rikerom, njen status je dvojan; zapravo mešovit. Nužno, kao takav, on mora podrazumevati i hermeneutiku i energetiku.

Psihoanalitički iskazi, sami po sebi, ne mogu biti locirani unutar diskursa prirodnih nauka. Psihoanalizu je nemoguće svesti na neurologiju. I ne samo to. Psihoanalizu je nemoguće potkrepiti saznanjima koje nam donosi neurologija. U pitanju su potpuno različiti tipovi diskursa. Dakako, oni se međusobno ne isključuju. Ipak, nemoguće ih je (nekritički) poistovećivati. Realna dobit je premala, gubitak (same stvari) je nemerljiv.

S obzirom da se ona bavi psihičkom realnošću, psihoanalitičar ne govori o uzrocima, već o motivima. I to, ponajviše, o motivima koji su nesvesni, koji se nalaze izvan okvire svesne samorefleksije subjekta. Zbog toga što topografsko polje subjektivnosti samog (uvek konkretnog) subjekta analitičkog iskustva ne koincidira sa svesnim procesom (to jest svesni fenomeni, kao što je neurotični simptom, objašnjavaju se nesvesnim motivima) njena eksplanacija samo (na prvi pogled) može podsećati na uobičajeno shvaćenu kauzalnu eksplanaciju. ${ }^{33}$ Važno je uvideti razliku. Nesvesni uzroci (to jest motivi) su nedostupni posmatranju ili kvantifikovanju, kao u prirodnim naukama. Oni predstavljaju plod konstrukcije u analizi. Kako na jednom mestu veli Frojd: od naših pacijenata mi ne očekujemo da nam kažu ono što o sebi znaju, što su voljni da nam kažu; mi od njih očekujemo da nam, nehotice, o sebi kažu, upravo, ono čega sami nisu svesni. ${ }^{34}$

Pokušaj da se reformulišu psihoanalitički koncepti kako bi se zadovoljili kriterijumi teorije nauke, kaže Riker, izdaju samu suštinu analitičkog iskustva. Slobodno možemo dodati, bio bi to promašaj. Za psihoanalitičara (tj. za njegovu praksu) nisu relevantne empirijske činjenice,

\footnotetext{
${ }^{33}$ Up. Ricoeur, P., Freud and Philosophy: An Essay on Interpretation.

${ }^{34}$ Frojd, S., „Pitanje laičke analize“, u Spisi o psihoanalitičkoj tehnici II (19201935), Cathexis, Beograd, 1991, str. 34.
} 
na način na koji ih, recimo, poznaju opservacione nauke. To nisu činjenice koje su dostupne spoljašnjem posmatraču. Ono što je za psihoanalitičara (za njegovu praksu) relevantno isključivo su dimenzije spoljašnje sredine i to, upravo, onako kako bivaju doživljene od strane subjekta analitičkog iskustva; ono što je analitičaru bitno nije činjenica, već značenje koje je data činjenica (iskustvo) poprimilo u istoriji subjekta. ${ }^{35}$ To značenje je krajnje idiosinkratično, individualno. Otud Lakanovo određenje psihoanalize kao nauke o pojedinačnom. ${ }^{36}$

Ponašanje (odnosno, doživljavanje), stoga, za analitičara, ne može biti zavisna varijabla koja se da posmatrati. Ono je proizvod značenja koje subjekat pridaje (što sopstvenim, to i tuđim) akcidencijama. Još od Studija o histeriji, Frojd naglašava subjektivnu (to jest istorijsku, a ne hereditarnu) etiologiju neuroza. ${ }^{37}$

Istorija subjekta otkriva se u polju govora. Stoga je, kaže Riker, pravi objekat psihoanalize efekat značenja - simptomi, snovi, omaške - koje empirijska psihologija može da razmatra samo kao segment ponašanja.

Za analitičara, ponašanje je segment značenja. Svođenje na moguću dinamiku kauzaliteta organskog supstrata sasvim bi bilo neprimereno.

Zajedno sa Brojerom, Frojd tvrdi da histerici pate od reminiscencija. ${ }^{38}$ Konverzivni simptom ima status mnemičkog simbola, to jest simbola potisnutih sećanja. Simptom je mesto gde psiha pamti, upravo, ono što je svest potisnula. Paradoksalnost simptoma očituje dvojakost njegove prirode; on je psihički fenomen par excellence, istovremeno bivajući izmešten izvan granica subjektu dostupne (svesne) samorefleksije. Suština psihoanalize, od najranije prošlosti do naših dana, sadržana je u ovom iskazu.

Primenjujući katartički metod u tretmanu neurotičnih simptoma, ova dva autora (Brojer i Frojd) će uskoro otkriti da se asocijacije pacijenta ne zaustavljaju na aktuelnoj traumi, već da se kreću ka prošlim iskustvima, i to ne samo iz perioda puberteta već i iz perioda ranog detinjstva. Frojd kaže:

\footnotetext{
${ }^{35}$ Up. Ricoeur, P., Freud and Philosophy: An Essay on Interpretation.

${ }^{36}$ Up. Glynos J. and Stavrakakis, Y., Lacan and Science, Routledge, London, 2002.

${ }^{37}$ Up. Breuer, J., Freud, S., Studies on Hysteria, vol. II, SE, The Hogarth Press, London, 1893-1895.

${ }^{38}$ Ibid.
} 
„Ovaj regresivni pravac je postao važna karakteristika analize. Izgledalo je da psihoanaliza ne može ništa da objasni bez pozivanja na prošlost; doista svako patogeno iskustvo je uključivalo prethodno iskustvo koje je, iako po sebi nepatogeno, ipak zaodevalo potonje patogenim kvalitetom. ${ }^{\text {"39 }}$ Potom, menjala se teorija, menjala se i tehnika.

Frojd je uglavnom radio sa neurotičnim pacijentima u vreme kada su se još uvek razvijale psihijatrijske nomenklature. To, bar delimično, objašnjava izostanak dosledno razvijene ideje o psihotičnim mehanizmima iz Frojdove teorije, koje će, na sebi svojstven način, razviti pripadnici Klajnijanske i Lakanove škole.

U slučaju psihoza, kao i u slučaju dimenzije psihoticizma u poretku subjektiviteta, krećemo se u narcističkom (Lakan bi rekao) Imaginarnom poretku. Na nivou Imaginarnog registra, po prirodi stvari, izostaju simboli. Samim tim - i nesvesni sadržaji.

S tim u vezi nameće se pitanje: da li se, i na koji način, pomenuti klinički i teorijski uvidi uklapaju u tezu o neophodnosti hermeneutike $i$ energetike u psihoanalizi? Da li se u slučaju verbalnog oposredovanja psihotičnih fenomena može govoriti o interpretaciji u Frojdovom smislu te reči? Verbalna artikulacija sadržaja koji se nalaze sa one strane označitelja proizvodi konkretan efekat, to jest progresivno uvođenje subjekta simbolički poredak. Diskurs terapeuta, koji dovodi do konstituisanja odnosa sa Drugim, uverava nas Šošana Felman, ne funkcioniše kao konstativ već kao performativ. ${ }^{40}$

Nesvesno je diskurs Drugog. Sam Frojd to (na takav način) nikad nije rekao. Na osnovu svog čitanja Frojda, Lakan to izvodi iz njegovih (Frojdovih) tekstova. Dakle, učinjen je (ali sada na strogo formalnom planu) definitivan otklon psihoanalitičke doktrine od kakvog god zamislivog neurološkog redukcionizma. Isti onaj posao što ga je svojevremeno Frojd započeo (pišući mladalački tekst posvećen afaziji) konačno će dobiti svoju (slobodno možemo reći) filozofski domišljenu apoteozu. Izvesni korektiv

\footnotetext{
${ }^{39}$ Freud, S., The History of Psychoanalytic Movement, SE, vol. XIV, 1914, str. 10.

${ }^{40}$ Felman, S., Jacque Lacan and the Adventure of Insight.Psychoanalysis and Contemporary Culture, University Press, Harvard, 1987.
} 
lakanovskoj (semiotički profilisanoj) jednostranosti, videli smo, pružiće Andre Grin.

U svakom slučaju, sve bi ovo, pre svega, moglo značiti (to bi bio i zaključak ovog mog teksta) da je psihoanalitička teorija (a sa njom i praksa) prevalila dug razvojni put, krećući se od ranih tekstova (poput studije o afaziji i Projekta) konačno stigavši do jedne sasvim specifične škole viđenja normalnosti i patologije subjekta; u svojoj srži ona ima postavku o bitno ekscentričnom statusu nesvesnog u odnosu na punktualno shvaćen identitet individuuma.

\section{LITERATURA}

Breuer, J., Freud, S., Studies on Hysteria, vol. II, SE, The Hogarth Press, London, 1893-1895. Glynos J and Stavrakakis, Y., Lacan and Science, Routledge, London, 2002.

Green A., The Fabric of Affect in the Psychoanalytic Discourse, Routledge, London, 1999.

Griesenger, W., Mental Pathology and Therapeutics, William Wood \& Company 1882.

Freud, S. Zur Auffassung der Aphasien, Franz Deuticke, Leipzig und Wien 1891.

On Aphasia (A Critical Study). By Sigmund Freud. Translated by E. Stengel. New York: International Universities Press, Inc., 1953.

Freud, S., „Project for a Scientific Psychology“, Freud, A., Strachey, A., Tyson, A., Richards, A. The Standard Edition of the Complete Psychological Works of Sigmund Freud, Volume I (1886-1899): Pre-Psycho-Analytic Publications and Unpublished Drafts, Vintage Books, London, 2001.

Forester, J., Language and the Origins of Psychoanalysis, The Macmillan Press Ltd, London, 1980.

Freud, S., The History of Psychoanalytic Movement, SE, vol. XIV, 1914.

Freud, S., The Unconscious, SE, vol. XIV, Hogarth Press, London, 1915 ab, str.177.

Freud, S., Instincts and Their Vicissitudes, SE, vol. XIV, Hogarth Press, London, 1915 a, str. 121-122.

Frojd, S., Tumačenje snova, Novi Sad, Matica srpska, 1969.

Frojd, S., „Pitanje laičke analize”, u Spisi o psihoanalitičkoj tehnici II (1920-1935), Cathexis, Beograd, 1991.

Felman, S., Jacque Lacan and the Adventure of Insight. Psychoanalysis and Contemporary Culture, University Press, Harvard, 1987.

Man, T., Stvaraoci i dela, Matica srpska, Novi Sad, 1932. 
Solms, M., "Before and After Freud's Project", in: Neuroscience of the Mind, ed. Bilder R, LeFever F. F., The New York Academy of Science, New York, 1998.

Ricoeur, P., Freud and Philosophy: An Essay on Interpretation, Yale University Press, New Heaven, 1970. 


\author{
GORDANA VULEVIĆ \\ University of Belgrade, Faculty of Philosophy
}

\title{
THE MIXED NATURE OF PSYCHOANALYTIC DISCOURSE
}

\begin{abstract}
Since his monography On aphasia, Freud distanced himself from the neurological reductionism of his contemporaries. Pointing out that the phenomenon of aphasia must be understood as independent of the localization of lesia, Freud contributed to the understanding of the phenomenon of hysteria. The hysterical symptom could not be reduced to degenerative changes in the central nervous system. In the case of hysteria, word-presentation is split from thing-presentation. Neurotic symptom - and this is the essence of Freud's later doctrine - is cured when during the psychotherapeutic process, word presentation is linked with thingpresentation. The patient's discourse, his free associations, is mainly determined by his unconscious. In an analytic situation, it (unconscious) is revealed to us as discourse. It cannot be disputed. However, if the talking cure is to be the cure, it is necessary to connect the symbolic and the energetic. Linguistic re/interpretation is not an alternative to economic explanation. Dynamic of meaning implies physical (energetic).
\end{abstract}

Keywords: Psychoanalysis, discourse, unconscious, energetic, hermeneutic

Primljeno: 30.12 .2021 . Prihvaćeno: 12.3.2021. 
